\title{
Chelodina longicollis (Shaw 1794) - \\ Eastern Long-Necked Turtle, Common Long-Necked Turtle, Common Snake-Necked Turtle
}

\author{
Rod Kennett ${ }^{1}$, John RoE $^{2}$, Kate Hodges ${ }^{2}$, And Arthur Georges ${ }^{2}$ \\ ${ }^{1}$ North Australian Indigenous Land and Sea Management Alliance (NAILSMA), \\ Charles Darwin University, Darwin NT 0909, Australia [Rod.Kennett@cdu.edu.au]; \\ ${ }^{2}$ Institute for Applied Ecology, University of Canberra, ACT 2601, Australia \\ [roe@aerg.canberra.edu.au,hodges@aerg.canberra.edu.au,georges@aerg.canberra.edu.au]
}

Summary. - The eastern long-necked turtle, Chelodina longicollis (Family Chelidae), has a wide distribution throughout southeastern Australia. It occupies a broad range of freshwater aquatic habitats but is more abundant in shallow, ephemeral wetlands often remote from permanent rivers. Its propensity for long distance overland migration, coupled with a low rate of desiccation and the capacity to estivate on land, enable it to exploit highly-productive ephemeral habitats in the absence of competition from fish and other turtle species. In wetter periods, such habitats provide optimal conditions for growth and reproduction. In drier periods, however, turtles may need to seek refuge in permanent water where high population densities and low productivity can lead to reduced growth rates and reproductive output. The species is an opportunistic carnivore that feeds on a broad range of plankton, nekton and benthic macro-invertebrates, carrion, as well as terrestrial organisms that fall upon the water. It is relatively slow to mature (7-8 yrs for males and 10-12 yrs for females), lays between 6 and 23 hard-shelled eggs during spring and late summer, and can produce up to 3 clutches per year. Although currently considered common and not under major threat, the most widespread conservation concern for $\boldsymbol{C}$. longicollis is high nest predation from the introduced fox (Vulpes vulpes), and roads, pest fencing, and habitat changes brought about by prolonged drought and climate change, which present localized and potential future threats for certain populations.

Distribution. - Australia. Found throughout southeastern Australia, including southeastern Queensland, New South Wales, Victoria, and southeastern South Australia.

Synonymy. - Testudo longicollis Shaw 1794, Emys longicollis, Chelodina longicollis, Hydraspis longicollis, Chelys (Chelodina) longicollis, Chelydura longicollis, Chelodina longicollis longicollis, Chelodina novaehollandiae Duméril and Bibron 1835, Chelodina sulcata Gray 1856a, Chelodina longicollis sulcata, Chelodina sulcifera Gray 1856b, Chelodina longicollis sulcifera.

SubSPECIES. - None currently recognized.

Status. - IUCN 2008 Red List: Not Listed (= Least Concern, LR/lc) (assessed 1996, needs updating); CITES: Not Listed; Australian EPBC Act: Not Listed.

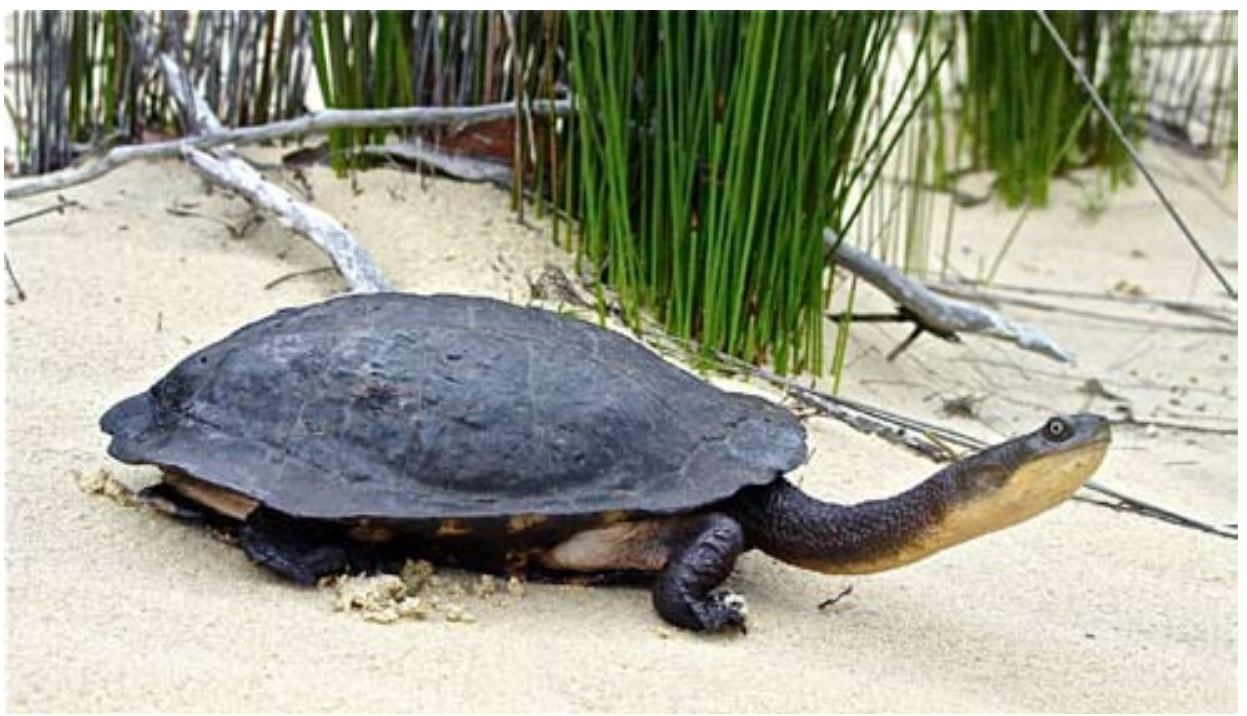

Figure 1. Adult female Chelodina longicollis from Booderee National Park, Jervis Bay, New South Wales, Australia. Photo by John Roe. 

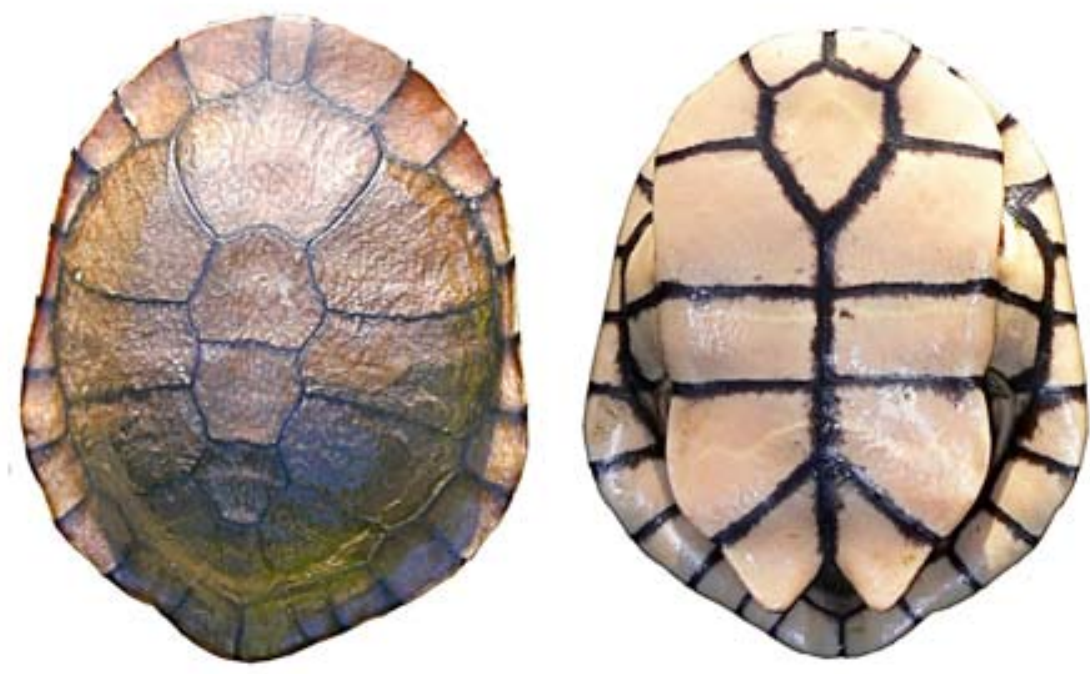

Figure 2. Dorsal and ventral view of the shell of a female Chelodina longicollis. Note the broadly expanded plastron, especially anteriorly, the darkening of the scute boundaries of the plastron, and the recessed intergular scute. Photos by Arthur Georges.

Taxonomy. - Chelodina longicollis was the first Australian freshwater turtle to be described, having been collected by Sir Joseph Banks during Captain Cook's first voyage down the eastcoast of Australia in 1770 (Cann 1998). First described as Testudo longicollis by Shaw (1794), it was subsequently considered distinct enough to be placed in its own genus Chelodina by Fitzinger (1826).

Chelodina sulcata, described by Gray (1856a) and then erroneously referred to as Chelodina sulcifera by Gray (1856b), was for a while recognized as distinct from C. longicollis (Müller 1936), but later shown to be a form of $C$. longicollis in which abnormal shell growth, possibly as a consequence of a dietary deficiency, resulted in the retention of impressions of earlier plastral scute growth (Budde 1968).

Several authors have noted morphological differences among some populations of $C$. longicollis. Chessman (1978) suggested that turtles east and west of the Great Dividing Range might be accorded subspecific status, and Beck (1991) proposed eastern and southern races, but these suggestions have not been supported by rigorous analysis. Neither arrangement is supported by mtDNA sequence

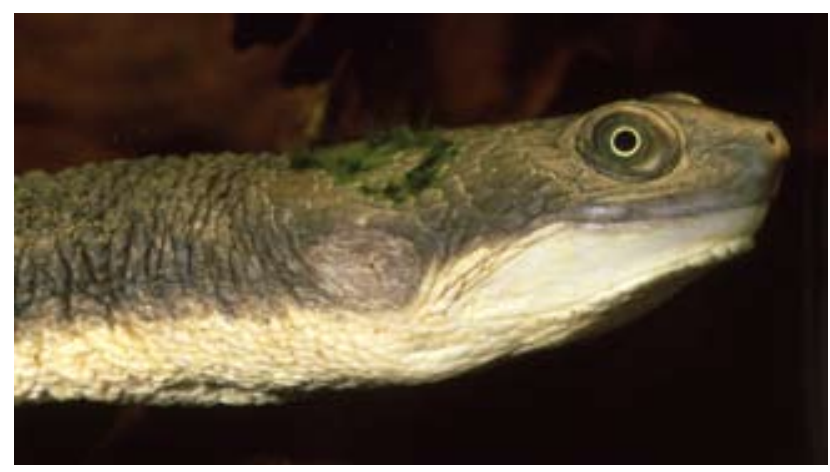

Figure 3. Head of Chelodina longicollis from Eastlakes Swamps, Sydney, New South Wales. Photo by John Cann. variation (Hodges, unpubl. data), and are not widely accepted. The taxonomy of the species is no longer regarded as controversial.

The genus Chelodina comprises three distinct clades (Goode 1967; Burbidge et al. 1974, Georges and Adams 1992: Seddon et al. 1997: Georges et al. 2002), commonly regarded to be subgenera (Legler 1985). Chelodina longicollis belongs to one of these clades (subgenus Chelodina), containing also C. steindachneri, C. canni, C. pritchardi, C. mccordi, C. reimanni, and C. novaeguineae. Chelodina longicollis is the sister taxon to the remaining species in the clade (Georges et al. 2002). The species hybridizes freely in nature with both $C$. canni and C. rugosa to produce viable offspring, but the processes that maintain genetic identity of the species are not known.

Description. - The carapace is moderately broad, expands slightly posteriorly and has a pronounced medial groove on the 2 nd to 4 th vertebrals that deepens with age. The marginals immediately above the tail are raised medially and the lateral marginals tend to curl upwards in older animals. The color of the carapace varies from black
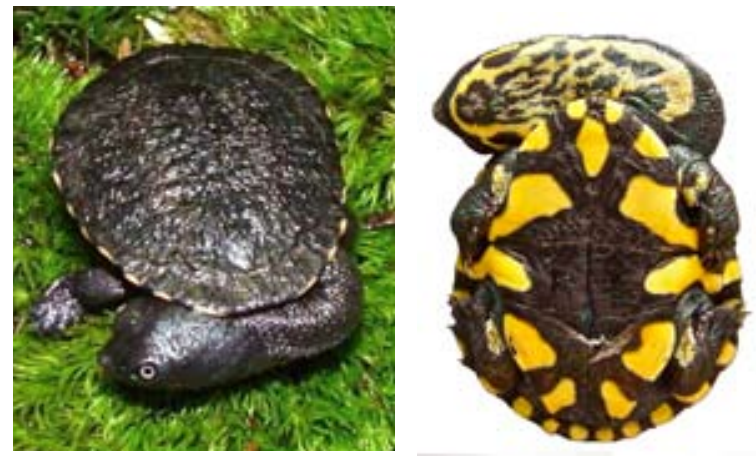

Figure 4. Dorsal and ventral view of a hatchling Chelodina longicollis. The distinctive bright orange coloration of the plastron fades with age. Photos by Oliver Römpp. 


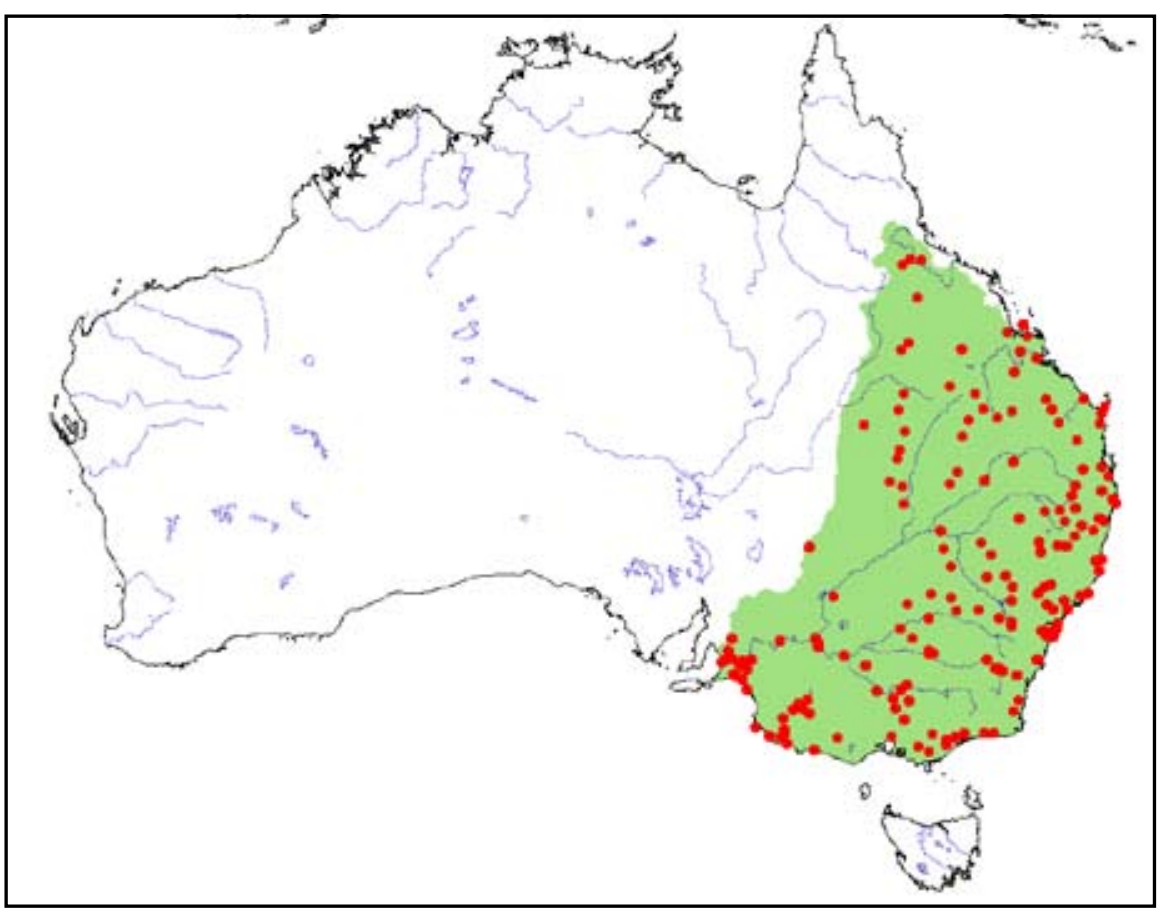

Figure 5. Distribution of Chelodina longicollis in Australia. Red points = museum and literature occurrence records based on Iverson (1992) plus more recent and authors' data; green shading = projected distribution based on GIS-defined hydrologic unit compartments (HUCs) constructed around verified localities and then adding HUCs that connect known point localities in the same watershed or physiographic region, and similar habitats and elevations as verified HUCs (Buhlmann et al., in press), and adjusted based on authors' data. Populations on Bass Strait islands north of Tasmania are considered introduced and are not shown here.

to light-brown, with the sutures outlined in black in lighter colored specimens. The plastron is large, usually extending laterally beyond the inner edges of the ventral surfaces of the marginal scutes that border the axillary pocket, and has a deep anal notch. It is cream in color with the sutures broadly edged in black. The neck is long, approximately $60 \%$ of the carapace length (CL) and covered with small pointed tubercles. Unlike the Chelodina within species group "B" (Goode 1967), the head and neck are relatively narrow and, when withdrawn, are protected by both carapace and plastron. The dorsal surfaces of the head, neck, and limbs are dark gray to brown and the undersides are cream to yellow. Both fore and hind limbs have four claws and the tail is quite short. When disturbed, it releases a pungent yellow fluid from inguinal and axillary scent glands that earns it the affectionate colloquial name of "stinker" (Eisner et al. 1978).

Females tend to have deeper shells, grow to larger sizes than males, and the ventral surface of the posterior lobe of their plastron is generally roundly convex as opposed to the concave or irregular shape of the males. The tail of the female tends to be shorter and fatter than the male but is usually withdrawn tightly into the shell when handled, thus the distinction is not always clear. Maximum adult body sizes vary geographically. Maximum female and male CL in riverine habitat in the Murray Valley are $282 \mathrm{~mm}$ and $249 \mathrm{~mm}$, respectively (Chessman 1978); in the ponds of the Gungahlin suburb in Canberra, ACT, they are $279 \mathrm{~mm}$ and $214 \mathrm{~mm}$ (Rees 2008); in farm dams near Armidale, NSW, they are $239 \mathrm{~mm}$ and $199 \mathrm{~mm}$ (Parmenter 1976); in dune lakes at Jervis Bay, NSW, they are $237 \mathrm{~mm}$ and $200 \mathrm{~mm}$ (Kennett 1987); and in the Latrobe Valley they are $216 \mathrm{~mm}$ and $188 \mathrm{~mm}$ (Chessman 1978). These differences likely reflect local habitat productivity as much as any broad latitudinal trends (Kennett 1987).

Hatchlings are almost entirely black, with a vivid orange stripe running along either side of the lower jaw and neck. Orange spots are present in the center of each plastral shield and the underside of the marginal scutes of the carapace. This vivid coloration may serve to warn aquatic predators of the unpalatability of the hatchling (Dorrian and Ehmann unpubl. data). Hatchlings have a mass of $4-5 \mathrm{~g}$ and are ca. $30 \mathrm{~mm}$ in CL.

Distribution. - Chelodina longicollis is distributed throughout southeastern Australia, from the vicinity of Port Lincoln on the Eyre Peninsula west of Adelaide in South Australia, throughout the coastal rivers of Victoria and New South Wales (NSW) north to the Fitzroy River drainage of coastal Queensland. It is found throughout the Murray-Darling drainage, in the Paroo drainage and in the headwaters of the Cooper Creek drainage in inland eastern Australia. Specimens have been recorded west of the Great Dividing Range as far north as the Burdekin River.

Early reports of $C$. longicollis from tropical northern Australia are probably Chelodina canni (Kennett et al. 1992). Where the species comes into contact with $C$. canni, in the coastal plains of the Styx River drainage in Queensland, the two species freely hybridize (Georges et al. 2002). Chelodina longicollis occurs in sympatry with Emydura macquarii and Chelodina expansa throughout 
much of the southern portion of its range (Chessman 1978; Chessman 1988a) and with Elseya albagula, Myuchelys latisternum, Emydura krefftii, and C. expansa in the north (Legler and Cann 1980; Georges 1982b).

There are apparently introduced populations on some of the islands in the Bass Strait north of Tasmania, specifically Chappell Island in the Flinders group (W. Austr. Mus. 12049) and King Island (Templeton 1972).

Habitat and Ecology. - Chelodina longicollis is active and can forage at low temperatures (Chessman 1988b); consequently it is able to penetrate into higher latitudes and altitudes than other Australian turtles. The species utilizes a broad range of habitats throughout its range, including permanent riverine waterholes, lakes, farm dams, and shallow temporary ponds. However, it occurs in greatest abundance in shallow, ephemeral waterholes or in bodies of water that are remote from permanent rivers, often in the absence of other turtle species (Chessman 1988a). Primarily a bottom dwelling species, it is rarely seen swimming at the surface, but occasionally leaves the water to bask (Webb 1978). It is most active in the early morning and late afternoon (Chessman 1988b).

Chelodina longicollis exhibits a suite of characteristics that enable it to exploit ephemeral and semi-permanent waterholes, including (1) a marked propensity for overland travel and ability to navigate (Stott 1987; Graham et al. 1996; Roe and Georges 2007); (2) a slow rate of desiccation (Chessman 1984a; Roe et al., 2008); and an ability to (3) drink pooled water while terrestrial; (4) absorb free water through its cloaca; and (5) physiologically adjust the composition of its urine to retain salts and reduce water loss (Rogers 1966; Roe 2008). These behavioral and physiological attributes allow $C$. longicollis to either estivate on land to await the re-flooding of wetlands, or to travel overland to permanent water bodies (Chessman 1983; Roe and Georges 2008a, b). An estivation duration of up to 480 days, without returning to water, has been observed (Roe and Georges 2007); however, energy stores ultimately limit survival out of water where they cannot feed (Roe et al. 2008). Estivation sites are typically located under canopy in forested habitats where turtles bury in leaf litter several $\mathrm{cm}$ deep near woody structures such as shrubs and logs, maintaining lower shell temperatures than when active (Roe et al. 2008; Rees 2008). Terrestrial estivation can continue into winter, requiring turtles to hibernate on land.

The migratory habits of $C$. longicollis are well known (Anonymous 1941; Stott 1987; Chessman 1988a; Beck 1991). The species is regularly encountered crossing roads that traverse wetland areas and colonizes farm dams within a few years of their construction (Parmenter 1976). In some cases overland migrations are extremely frequent, with some individuals (males, females, and juveniles) associating with several different water bodies during a single year (Roe 2007; Rees 2008; Roe et al. 2009). Overland travel usually coincides with rainfall and treks covering several kilometers and more than 40 days on land have been reported (Chessman 1978; Stott

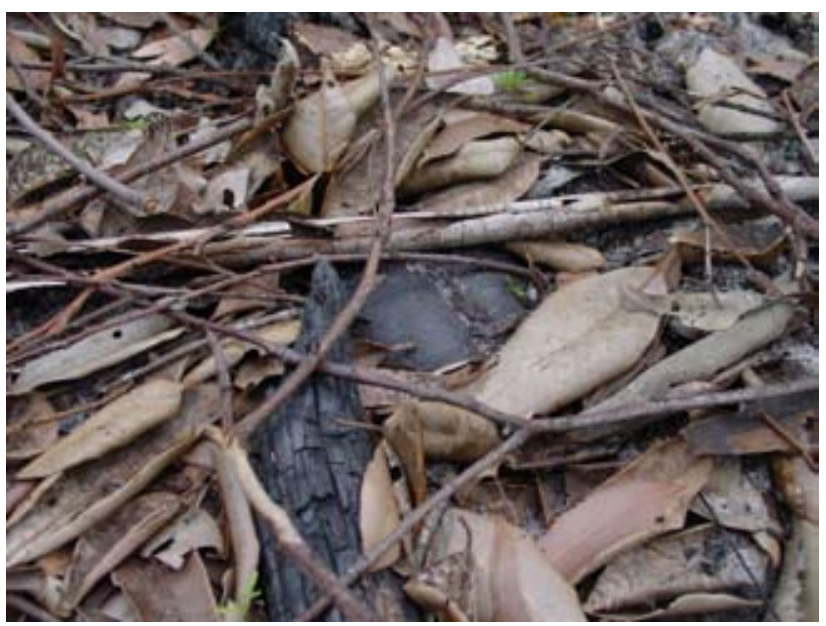

Figure 6. Chelodina longicollis has a strong propensity for overland migration, and can spend extensive periods estivating in terrestrial refugia. This animal is buried in leaf litter in Booderee National Park. Photo by John Roe.

1987; Roe et al. 2008). Overland migration enables $C$. longicollis to exploit abundant food resources in temporary water bodies in the absence of competition from fish and other species of turtle (Chessman 1984b; Georges et al. 1986; Chessman 1988a). At Jervis Bay, NSW, terrestrial migration is part of a dynamic pattern of habitat utilization (Kennett 1987; Kennett and Georges 1990; Roe et al. 2009). In drier periods, most turtles are confined to the refuge of permanent freshwater dune lakes where high population densities coupled with low productivity result in drastically reduced growth and reproduction. In wetter periods, turtles move out into ephemeral wetlands where conditions for growth and reproduction are extremely favorable (Kennett and Georges 1990; Roe and Georges 2008a). Competitive exclusion by other turtle species and

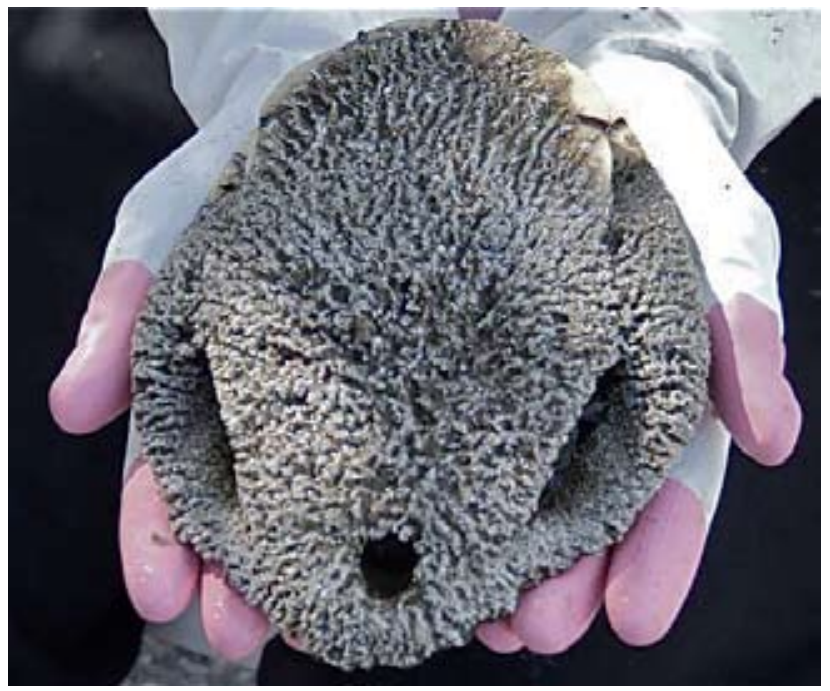

Figure 7. The range of habitats occupied by Chelodina longicollis includes brackish waters. Increased salinization of Australia's freshwater rivers is a threat to freshwater turtles, and leads to novel encounters, in this case, of a turtle and an encrusting estuarine tube worm in Lake Alexandrina, South Australia. This animal was still alive, but suffering restrictions on its mobility. Photo by Sally Grundy. 
fish may explain its relatively scarcity in large permanent waterholes elsewhere in its range (Chessman 1978; Georges et al. 1986).

Chelodina longicollis is an opportunistic carnivore that feeds on a broad range of planktonic, nektonic, and benthic macro-invertebrates, carrion, as well as terrestrial organisms that fall upon the water (Parmenter 1976; Chessman 1984b; Georges et al. 1986). Turtles feed with a "strike and gape" action in which prey are effectively sucked into the mouth by a vacuum created when the hyoid is lowered (Parmenter 1976). The composition of the diet varies little with the size or sex of the turtle, except that adults tend to eat more carrion. Competition with fish may significantly reduce dietary intake because turtles occupying waterholes with fish had significantly lower stomach content volumes than turtles in waterholes without fish (Chessman 1984b). Turtles are not selective in the animals that they eat and geographic variation in their diet probably results from differences in local abundances of prey (Georges et al. 1986).

Data on growth rates are limited to populations in the southerly portion of its range where turtles become inactive during cold winter months and feeding and growth cease (Chessman 1988b). Growth rates are also markedly influenced by food availability. Kennett and Georges (1990) demonstrated significant differences between local populations in both adult and juvenile growth rates that correlated with measured differences in food availability between the habitats. Turtles in a highly productive ephemeral swamp grew substantially faster than those in permanent dune lakes where food availability was lower. Growth rates of turtles in the lakes were faster in wetter years when the area of useable habitat and presumably food availability were greatest; whereas, many individuals, both adults and juveniles, failed to grow at all during drier years. Growth and adult body size differences were also observed between turtles in suburban ponds and an adjacent nature reserve in the ACT. The faster growth rates and larger body sizes of suburban turtles were hypothesized to reflect high nutrient runoff from golf courses, roads, and gardens, as well as the more stable water levels from urban runoff that afforded suburban turtles a longer growing season over those of the nature reserve, where wetlands dried for several months of the year and forced the turtles to estivate (Rees 2008; Rees et al. in press).

Size at maturity varies geographically but shows no clear latitudinal trends. The largest sizes at maturity are recorded in the Murray Valley (NSW and Victoria), where males mature at CL of 180-190 $\mathrm{mm}$ and females at $210 \mathrm{~mm}$ (Chessman 1978). Smaller sizes are reported from Jervis Bay (NSW), Armidale (NSW) and the Latrobe Valley (Victoria) where males mature at CL of 142-152 mm and females at 165-185 mm (Parmenter 1976; Chessman 1978; Kennett and Georges 1990). Age estimation is hampered by erratic growth and the loss and non-annual formation of scute annuli (Stott 1988), but the available data suggest that age at maturity is less variable than size. Males and females at Armidale (NSW) mature at 7 and 10-11 yrs respectively, similar to the 8-12 yrs for turtles from the Murray River (Chessman 1978). Growth rates of juvenile turtles also vary geographically. Kennett and Georges (1990) recorded average juvenile $(\mathrm{CL}=80 \mathrm{~mm})$ growth rates at Jervis Bay of $7 \mathrm{~mm} / \mathrm{yr}$, compared to around $22 \mathrm{~mm} / \mathrm{yr}$ for similar sized juveniles in the Murray Valley (Chessman 1978). Mean adult growth rates are uniformly low, often less than $1 \mathrm{~mm} /$ $\mathrm{yr}$, and many adults do not grow at all for long periods. For example, mature females occupying a large semi-natural waterhole near Canberra, showed no measurable increase in size when re-measured 20 years after first capture (Georges, unpubl. data).

Estimates of longevity in natural populations are rare given that turtles are difficult to age past the point at which they mature, and few long term capture-recapture studies have been undertaken for long enough to document longevity. Parmenter (1985) speculated that, at an average adult growth rate of $0.51 \mathrm{~mm} / \mathrm{yr}$, a recently matured female of $170 \mathrm{~mm}$ and $10 \mathrm{yrs}$ of age would take $143 \mathrm{yrs}$ to reach the maximum size of $240 \mathrm{~mm}$. This is likely to be an overestimate because few turtles actually reach the maximum recorded size for a population, but it suggests that wild turtles are likely to live at least as long as captive animals (36 yrs, Goode 1967; 37+ yrs, Goin and Goin 1971 in Parmenter 1976). In the longest reported continuous study of this species, several turtles captured as adults in 1983 were recaptured as late as 2007 in our Jervis Bay, NSW studies, indicating minimum ages of 31-34 yrs in the wild (Roe 2007).

Adult survivorship in populations occupying permanent water in farm dams is high $(98 \%$ per year, Parmenter 1985). Survivorship rates of turtles in the dune lakes of Jervis Bay, NSW, ranged from $85 \%$ to $94 \%$ for both juveniles and adults (Roe et al. 2009), but lower survival rates $(55 \%)$ were observed for turtles estivating near dry ephemeral wetlands during a prolonged drought (Roe and Georges 2008a). Predators on adults include the Whitebreasted Sea Eagle (Haliaeetus leucogaster), dingos (Canis familiaris) and foxes (Vulpes vulpes), and many are killed by motor vehicles on roads or when entrapped by pest-proof fencing (J. Roe, pers. obs.).

Mating usually occurs in September (Chessman 1978; Parmenter 1985; Kennett and Georges 1990) and lacks the often elaborate courtship behaviors that occur in other species (Murphy and Lamoureaux 1978). Nesting occurs in the late spring and early summer (October - January) and up to three clutches containing between 6 and 23 eggs (average of 14) are laid (Vestjens 1969; Parmenter 1976, 1985; Chessman 1978; Legler 1985; Georges, unpubl. data). Eggs are white, hard-shelled and ellipsoid in shape, about $20 \mathrm{~mm}$ wide and $30 \mathrm{~mm}$ long and weigh 6-7 g. Females may travel up to $500 \mathrm{~m}$ or more from water to preferred nesting sites on a crest or ridge at the top of a slope and will nest in a variety of substrates from soft sand to hard clay or even gravel roads. Water is periodically released from the cloaca into the nest to soften the ground 
(Vestjens 1969) and one female was observed to return to the water several times to take on more water before she was able to complete nesting (Cann 1978). Once the eggs have been laid the female pushes earth back into the hole with her rear feet and tamps it down by raising herself on her legs above the nest and dropping abruptly to compact the earth.

Despite the female's attempts to camouflage her nest, predation on nests is high. Parmenter (1985) reported a minimum estimate of $49 \%$ of nests destroyed, Beck (1991) and Thompson (1983) reported predation rates in excess of $90 \%$. Predators include native animals such as water rats (Hydromys chrysogaster), goannas (Varanus sp.) and Australian ravens (Corvus coronoides) but most nests (> 90\%) are destroyed by the introduced fox (Thompson 1983; Parmenter 1985; Beck 1991). Eggs in nests that escape predation take between 110 and 150 days to complete incubation and hatchlings emerge in autumn, usually after rain has softened the ground (Parmenter 1985; Vestjens 1969). Overwintering in the nest by hatchlings has not been directly observed but may occur in populations in Gippsland, Victoria (Parmenter 1985; Chessman 1978).

Clutch size or number of clutches per year varies among populations but no clear latitudinal trends are apparent. Larger females tend to lay larger clutches, hence estimates of clutch size will be influenced by the size distribution of females sampled from a population. Reproductive output also varies with annual and spatial variation in food availability (Kennett and Georges 1990), further obscuring any geographical trends. Under good conditions all females in a population will nest but reproduction is depressed and may cease entirely in overcrowded conditions or where food is severely limited (Kennett and Georges 1990).

Adult sex ratios in natural populations range from equal to both male and female biased (Parmenter 1976; Kennett and Georges 1990). Females in a crowded drought refuge maintained better body condition (i.e., were heavier) than equivalent sized males, suggesting that female-biased sex ratios may result from male-biased mortality during times of severe food limitation (Kennett and Georges 1990). Rees (2008) did not observe skewed sex ratios in areas bisected by suburban roads. Skewed adult sex ratios are unlikely to be the result of biased hatchling sex ratio because hatchling sex is genetically determined, and not temperature-dependent as in many other turtle species (Georges 1988; Palmer-Allen et al. 1991).

Population Status. - Chelodina longicollis is common in all major river systems throughout its broad range. While agricultural and urban development has had adverse effects on the natural habitat of the species, this may have been offset by the construction of numerous artificial water bodies for agricultural and pastoral purposes (Parmenter 1976; Rennie 2002; Doody et. al. 2006). It is also likely that the provision of new habitats such as dams, river impoundments, irrigation channels, and urban ponds have facilitated population expansion into areas that may have been previously inaccessible due to physical barriers such as extensive stretches of dry land (Beck 1991; Doody et. al. 2006; Rees et al. in press; Roe and Georges in press).

Estimates of population densities range from 26 to 400 turtles/ha (Parmenter 1976; Chessman 1978; Georges 1982a). Large fluctuations in population size may result from climate-mediated mass immigration or emigrations of turtles (Kennett and Georges 1990; Roe et al. 2009).

There are anecdotal reports of appreciable declines in populations in the Brisbane catchment of southeast Queensland over the past 20 years. This may be due to the combined factors of increased wetland loss and degradation associated with urban development, increased road mortality of migrating turtles and increased fox predation (John Cann, pers. comm.).

Threats to Survival. - The introduced fox is the primary predator on nests and, in some years and locations, every nest is destroyed. Turtle populations in habitats where fox predation is high are often dominated by larger (= older) adults and juveniles are absent (Thompson 1983). This lack of successful nesting and juvenile recruitment has prompted concerns that the long term survival of many populations of C. longicollis is in jeopardy, but that in the short term, such population declines are masked by the longevity of adults (Thompson 1983; Thompson 1993a; Thompson 1993b). Foxes also kill adults and large winter kills of turtles by foxes have been observed (Georges, unpubl. data).

Riverine habitat modification for agricultural industries and urban development threaten populations of C. longicollis. Water has been extracted from Australia's Murray-Darling Basin, the primary inland habitat for $C$. longicollis, since the early 1900s, and approximately $75 \%$ of the flow of water in the Murray-Darling Basin is now redirected for human use. Changes in river flow, discharge and flood frequency, the addition of physical barriers to movement, increased river and dry land salinity, and a decline in water and habitat quality due to prolonged drought and climate change all have negative impacts on the abundance and distribution of C. longicollis (Roe and Georges in press). Habitat modification especially affects populations of $C$. longicollis, where productive semipermanent wetlands are converted to permanent water lakes such as occurred in Lake Mokoan in Victoria (Cann 1993). Toxic algal blooms coupled with a reduced food availability in the lake led to the starvation and eventual death of large numbers of turtles.

Migrating turtles travel long distances overland (distances of $8 \mathrm{~km}$ have been reported) and such movements between habitats are an essential part of the species' strategy of habitat use. Land use changes such as roads and fencing that impede the free travel of turtles may have a deleterious impact on populations over a broad area. However, Rees (2008) concluded that populations in suburban Canberra were not severely threatened by roads and other urban hazards. Most turtles could avoid crossing roads during their normal movements by travelling through under-road stormwater drainage culverts (Rees et al. in press). 
Conservation Measures Taken. - The species is currently protected under both state and federal legislation which prohibits the taking and killing of native wildlife by all except Aboriginal people and Torres Strait Islanders. It is regarded as a common species by all States and Territories where it occurs, and individuals may be kept without a permit provided they are not collected from the wild and are obtained from a legal source. Overseas export of native animals is regulated by the Environment Protection and Biodiversity Act 1999 administered by the Australian government.

Chelodina longicollis is largely ubiquitous within permanent and ephemeral freshwater and brackish wetlands of all varieties and so is found in all national parks and protected areas within its occupied range, including the following National Parks (among many others): Booderee, Jervis Bay, Seven Mile Beach, and Thirlmere Lakes in New South Wales.

Conservation Measures Proposed. - Specific conservation plans for $C$. longicollis are not a high priority and have not been formulated, as the species is considered common throughout its range.

Captive Husbandry. - Chelodina longicollis are hardy in captivity and thrive on a balanced diet of fish, tadpoles, invertebrates and prepared food. Eggs can be readily obtained by hormonal injections to induce egglaying.

Current Research. - Current mtDNA based studies of the phylogeography of $C$. longicollis are underway (Hodges, unpubl. data) and the taxonomy and biogeography of the entire genus Chelodina is currently under review (Georges and Thomson, 2009).

\section{LITERATURE CITED}

ANONYMous. 1941. Death on the plains-where instinct fails. Wild life (Melbourne.) 3:13-14.

Beck, R.G. 1991. The Common Longnecked Tortoise Chelodina longicollis (Shaw 1802) (Testudinata: Chelidae): A comparative study of the morphology and field behaviour of disjunct populations. South Australian Naturalist 66:4-22.

Beynon, F. 1991. Comparative rates of oxygen consumption and development in two species of turtle from the genus Chelodina. Honours Dissertation, University of Canberra, Canberra.

Budde, H. 1968. A rare Australian chelid? International Turtle and Tortoise Society Journal 2(5):12-15.

Buhlmann, K.A., Akre, T.S., Iverson, J.B., Karapatakis, D., MitTermeIER,R.A.,GeORGES,A., Rhodin,A.G.J., vANDiJk,P.P., AND GiBBons, J.W.In press.Aglobal analysis of tortoise and freshwater turtle distributions withidentification of priority conservation areas. Chelonian Conservation and Biology 8(2):in press.

Burbidge, A.A., KIRSCH, J.A.W. And MaIN, A.R. 1974. Relationships within the Chelidae (Testudines: Pleurodira) of Australia and New Zealand. Copeia 1974:392-409.

CAnN, J. 1978. Tortoises of Australia. First Edition. Angus and Robertson, Sydney.

CANN, J. 1993. Don't take our freshwater turtles for granted. In: Lunney, D. and Ayers, D. (Eds.). Herpetology in Australia - A Diverse Discipline. Transactions of the Royal Zoological Society of
New South Wales. Surrey Beatty and Sons, Sydney, pp. 363-65.

CAnN, J. 1998. Australian Freshwater Turtles. Sydney and Singapore: Beaumont Publishing, 292 pp.

Chessman, B.C. 1978. Ecological studies of freshwater turtles in south-eastern Australia. Ph.D. Dissertation, Monash University, Melbourne.

Chessman, B.C. 1983. A note on aestivation in the Snake-necked Turtle, Chelodina longicollis (Shaw) (Testudines: Chelidae). Herpetofauna 14:96-97.

Chessman, B.C. 1984a. Evaporative water loss from three southeastern Australian species of freshwater turtle. Australian Journal of Zoology 32:649-655.

Chessman, B.C.1984b. Food of the Snake-Necked Turtle, Chelodina longicollis (Shaw) (Testudines: Chelidae) in the Murray Valley, Victoria and New South Wales. Australian Wildlife Research 11:573-578.

Chessman, B.C. 1988a. Habitat preferences of freshwater turtles in the Murray Valley, Victoria and New South Wales. Australian Wildlife Research 15:485-91.

Chessman, B.C. 1988b. Seasonal and diel activity of freshwater turtles in the Murray Valley, Victoria and New South Wales. Australian Wildlife Research 15:267-76.

Doody, S., Osborne, W., Bourne, D., Rennie, B. and Sims, R. 2006. Vertebrate Biodiversity on Australian Rice Farms: An Inventory of Species, Variation Among Farms, and Proximate Factors Explaining that Variation. Rural Industries Research and Development Corporation, Canberra Australia. Publication No. W05/198. Project No. UCA-6A.

DumÉrIL, A.M.C. AND Bibron, G. 1835. Erpetologie Generale ou Histoire Naturelle Complete des Reptiles. Roret, Paris, 680 pp.

Eisner, T., Jones, T.H., Meinwald, J., And Legler, J.M. 1978. Chemical composition of the odorous secretion of the Australian turtle, Chelodina longicollis. Copeia 1978:714-715.

FitzINGER, L.J. 1826. Neue classification der reptilien nach ihren naturlichen verwandtschaften. Vienna: Heubner. 66 pp.

Georges, A. 1982a. Diet of the Australian freshwater turtle Emydura krefftii (Chelonia: Chelidae), in an unproductive lentic environment. Copeia 1982:331-336.

Georges, A. 1982b. Ecological studies of Krefft's River Tortoise, Emydura kreftii, from Fraser Island, Queensland. Ph.D. Dissertation, University of Queensland, Brisbane.

GEORGES, A. 1988. Sex determination is independent of incubation temperature in another chelid turtle, (Chelodina longicollis). Copeia 1988:248-254.

Georges, A. AND AdAms, M. 1992. A phylogeny for Australian chelid turtles based on allozyme electrophoresis. Australian Journal of Zoology 40:453-476.

Georges A., Adams M. And McCord, W. 2002. Electrophoretic delineation of species boundaries within the genus Chelodina (Testudines: Chelidae) of Australia, New Guinea and Indonesia. Zoological Journal of the Linnean Society 134:401-421.

Georges A. And Thomson S. 2009. Diversity of Australasian freshwater turtles, with an annotated synonymy and keys to species. Zootaxa, in review.

Georges, A., Norris, R. and Wensing, L. 1986. Diet of the freshwater turtle Chelodina longicollis (Testudines: Chelidae), from the coastal dune lakes of the Jervis Bay Territory. Australian Wildlife Research 13:301-308.

Goode, J. 1967. Freshwater tortoises of Australia and New Guinea. Lansdowne Press Pty Ltd, Melbourne.

Graham T.E., Georges A. And McElhinney, N. 1996. Terrestrial orientation by the eastern long-necked turtle, Chelodina longicollis, from Australia. Journal of Herpetology 30:467-477. 
GRAY, J.E. 1856a. On some new species of freshwater tortoises from North America, Ceylon and Australia, in the collection of the British Museum. Proceedings of the Zoological Society of London 1855[1856](23):197-202.

GraY, J.E. 1856b [“1855"]. Catalogue of Shield Reptiles in the Collection of the British Museum. Part I. Testudinata (Tortoises). British Museum, London, 79 pp.

IVERSON,J.B. 1992.ARevised Checklist with Distribution Maps of the Turtles of the World. Richmond, IN: Privately printed, 363 pp.

KenNETT,R. 1987. Reproduction, growth and dispersal of the eastern long-necked turtle Chelodina longicollis Shaw (Testudinata: Chelidae) in the Jervis Bay Territory'. Honours Dissertation, Australian National University, Canberra.

Kennett, R.M. And Georges, A. 1990. Habitat utilization and its relationship to growth and reproduction of the eastern longnecked turtle, Chelodina longicollis, (Testudinata: Chelidae), from Australia. Herpetologica 46:22-33.

Kennett, R.M., Georges, A., Thomas, K. and Georges, T.C. 1992. Distribution of the long-necked freshwater turtle Chelodina novaeguineae and new information on its ecology. Memoirs of the Queensland Museum 32:179-182.

Legler, J. 1985. Australian chelid turtles: reproductive patterns in wide-ranging taxa. In: Grigg, G., Shine, R. and Ehmann, H. (Eds.). Biology of Australasian Frogs and Reptiles. Royal Zoological Society of New South Wales, Sydney, pp. 117-123.

LEGLER, J.M. AND CANN, J. 1980. A new genus and species of chelid turtle from Queensland, Australia. Contributions to Science (Los Angeles County Museum of Natural History) 324:1-18.

MüLLER,L. 1936. Über die Artberechtigung von Chelodina sulcifera Gray. Zoologische Anzeiger, Leipzig 116:273-287.

MurPhy, J.B. AND LAmourEauX, W.E. 1978. Mating behaviour in three Australian chelid turtles (Testudines: Pleurodira: Chelidae). Herpetologica 34:398-405.

Palmer-Allen, M., Beynon, F. and Georges, A. 1991. Hatchling sex ratios are independent of temperature in field nests of the long-necked turtle, Chelodina longicollis (Testudinata: Chelidae). Wildlife Research 18:225-231.

PARMENTER, C.J.1976. The natural history of the Australian freshwater turtle Chelodina longicollis Shaw (Testudinata: Chelidae). Ph.D. Dissertation, University of New England, Armidale.

PARMENTER, C.J. 1985. Reproduction and survivorship of Chelodina longicollis (Testudinata: Chelidae). In: Grigg, G., Shine, R. and Ehmann, H. (Eds.). Biology of Australasian Frogs and Reptiles. Royal Society of New South Wales, Sydney, pp. 53-61.

REES, M. 2008. Impacts of urbanisation on the eastern long-necked turtle (Chelodina longicollis). Honours Dissertation, University of Canberra, Canberra, ACT.

Rees, M., Roe, J.H., AND Georges, A. In press. Life in the suburbs: Behavior and survival of a freshwater turtle in response to drought and urbanization. Biological Conservation.

RENNIE,B.A. 2002. Habitat use and movement patterns of the eastern long-necked turtle (Chelodina longicollis) in rice agroecosystems of N.S.W. Unpublished Honours Dissertation, University of Canberra, Canberra.

RoE, J.H. 2007. The terrestrial ecology of a freshwater turtle, Chelodina longicollis, in Booderee National Park,Australia.Ph.D. Dissertation, University of Canberra, Canberra, ACT.

RoE, J.H. 2008. Chelodina longicollis (Eastern long-necked turtle). Drinking Behavior. Herpetological Review 39:212-213.

RoE,J.H. AND GEORGES,A.2007. Heterogeneous wetland complexes, buffer zones, and travel corridors: landscape management for freshwater reptiles. Biological Conservation 135:67-76.

RoE,J.H. AND GEORGES,A.2008a. Maintenance of variable responses for coping with wetland drying in freshwater turtles. Ecology 89:485-494.

Roe, J.H. And Georges, A. 2008b. Terrestrial activity, movements, and spatial ecology of an Australian freshwater turtle, Chelodina longicollis in a temporally dynamic wetland system. Austral Ecology 33:1045-1056.

RoE, J.H. AND GeORGES, A. In press. Responses of freshwater turtles to drought: the past, present and future implications of climate change in Australia. In Gow, K. and Paton, D. (Eds.). The Phoenix of Natural Disasters: Impact of Drought. Nova Science Publishers, New York.

Roe, J.H., Georges, A. AND Green, B. 2008. Energy and water flux during terrestrial estivation and overland movement in a freshwater turtle. Physiological and Biochemical Zoology 81:570-583.

Roe, J.H., Brinton, A.C., Georges, A. 2009. Temporal and spatial variation in landscape connectivity for a freshwater turtle in a temporally dynamic wetland system. Ecological Applications 19:1288-1299.

Rogers, L.J. 1966. The nitrogen excretion of Chelodina longicollis under conditions of hydration and dehydration. Comparative Biochemistry and Physiology 18:249-260.

Seddon J.M., Georges A., Baverstock P.R., ANd McCord W. 1997. Phylogenetic relationships of chelid turtles (Pleurodira: Chelidae) based on mitochondrial 12S rRNA gene sequence variation. Molecular Phylogenetics and Evolution 7:55-61.

SHaw, G. 1794. The Zoology of New Holland. British Museum of Natural History, London.

STOTт, P. 1987. Terrestrial movements of the freshwater tortoise, Chelodina longicollis (Shaw), as monitored with a spool tracking device. Australian Wildlife Research 14:559-567.

Sтотт, P. 1988. Use of growth rings to determine age on the freshwater tortoise Chelodina longicollis: a cautionary note. Transactions of the Royal Society of South Australia 112: 179-180.

Templeton, M.T. 1972. Reptiles of King Island. Tasmanian Naturalist 31:1-2.

Thompson, M.B. 1983. Populations of the Murray River Tortoise Emydura (Chelidae): the effect of egg predation by the red fox, Vulpes vulpes. Australian Wildlife Research 10:363-371.

Thompson, M.B. 1993a. How secure are "common tortoises"? Australian Natural History 24:72.

Thompson, M.B. 1993b. Hypothetical considerations of the biomass of chelid tortoises in the River Murray and the possible influences of predation by introduced foxes. In: Lunney, D. and Ayers, D. (Eds.). Herpetology in Australia - ADiverse Discipline. Transactions of the Royal Zoological Society of New South Wales. Surrey Beatty and Sons, Sydney, pp. 219-224.

VestJens, W.J.M. 1969. Nesting, egg-laying and hatching of the snake-necked tortoise at Canberra, A.C.T. The Australian Zoologist 15:141-151.

WeBB, G.J.W. 1978. Observations on basking in some Australian turtles (Reptilia: Testudines: Chelidae). Herpetologica 34:39-42.

\section{Citation Format for this Account:}

Kennett, R., Roe, J., Hodges, K., And Georges, A. 2009. Chelodina longicollis (Shaw 1784) - eastern long-necked turtle, common long-necked turtle, common snake-necked turtle. In: Rhodin, A.G.J., Pritchard, P.C.H., van Dijk, P.P., Saumure, R.A., Buhlmann, K.A., Iverson, J.B., and Mittermeier, R.A. (Eds.). Conservation Biology of Freshwater Turtles and Tortoises: A Compilation Project of the IUCN/SSC Tortoise and Freshwater Turtle Specialist Group. Chelonian Research Monographs No. 5, pp. 031.1-031.8, doi:10.3854/crm.5.031. longicollis.v1.2009, http://www.iucn-tftsg.org/cbftt/. 